\title{
Diversity of Xanthomonas campestris Isolates from Symptomatic Crucifers in New York State
}

\author{
H. W. Lange, M. A. Tancos, M. O. Carlson, and C. D. Smart
}

Plant Pathology and Plant-Microbe Biology Section, School of Integrative Plant Science, Cornell University, Geneva, NY 14456. Accepted for publication 29 October 2015.

\begin{abstract}
Lange, H. W., Tancos, M. A., Carlson, M. O., and Smart, C. D. 2016. Diversity of Xanthomonas campestris isolates from symptomatic crucifers in New York State. Phytopathology 106:113-122.

To assess the diversity of Xanthomonas campestris spp. infecting crucifers in New York, 154 isolates were collected over 10 years across the state. The goal was to determine if isolates of the pathogen were overwintering in New York and serving as primary inoculum in subsequent years, or if novel isolates were entering the state each year. Pure cultures of isolates were characterized using multilocus sequence analysis (MLSA), a greenhouse pathogenicity assay, repetitive element-polymerase chain reaction (Rep-PCR) using the BOX-A1R primer, and enzyme-linked immunosorbent assay. The MLSA scheme proved to be more efficient than Rep-PCR for a large sample

population and for comparison with global isolates. X. campestris isolated from crucifers in New York comprised of $X$. campestris pv. campestris and $X$. campestris pv. raphani, with $X$. campestris pv. raphani being predominately isolated from transplants. Evidence for unique haplotypes persisting on the same farm for several years due to improper seedbed rotations was documented in addition to novel haplotypes being spread throughout states through infected transplants and seed. Rep-PCR confirmed the high diversity of $X$. campestris and was used to generate 15 unique fingerprint patterns from isolates collected in the first 5 years. A worldwide comparison of isolates suggests that the $X$. campestris pv. campestris population appears to be very homogenous with dominant haplotypes persisting for extended periods and being globally disseminated.
\end{abstract}

Xanthomonas campestris infections of cruciferous crops continue to threaten the economic viability of growers worldwide (Williams 1980). X. campestris is a seed-disseminated Gram-negative phytopathogenic bacterium that is a continual threat in tropical and subtropical areas where crucifers are planted year round, and it is an annual threat in temperate climates when temperatures are between 22 and $28^{\circ} \mathrm{C}$ with high humidity (Cook et al. 1952a). Wet conditions are conducive for epiphytic survival of the bacterium as well as the secondary spread between plants (Carisse et al. 1998).

$X$. campestris has been reclassified into six pathovars in order to incorporate distinctions in host infection, colonization, and symptom development among cruciferous plants, which currently include the following: X. campestris pv. campestris, $X$. campestris pv. aberrans, $X$. campestris pv. armoraciae, $X$. campestris pv. barbareae, $X$. campestris pv. incanae, and $X$. campestris pv. raphani (Vauterin et al. 1995). Much debate continues about $X$. campestris pv. armoraciae and $X$. campestris pv. raphani and whether they are synonymous or distinct pathovars (Alvarez et al. 1994; Bogdanove et al. 2011; Vicente et al. 2006). In the current study we will adopt the definition by Vicente et al. (2006) and define X. campestris isolates that cause nonvascular leaf spots on Brassica spp. as $X$. campestris pv. raphani.

In New York, black rot (X. campestris pv. campestris) occurs annually, with severe outbreaks causing economic impact when the growing season is warm and accompanied by wind-driven rains. Field maintenance practices such as cultivation, spray applications, and irrigation are all means of pathogen spread. Bacteria can readily

Corresponding author: C. D. Smart; E-mail address: cds14@ cornell.edu

First and second author authors contributed equally to this work.

*The $\boldsymbol{e}$-Xtra logo stands for "electronic extra" and indicates that two supplementary tables are published online.

http://dx.doi.org/10.1094/PHYTO-06-15-0134-R

(c) 2016 The American Phytopathological Society enter the plant through wounds, stomata (cotyledon stage), and hydathodes (Staub and Williams 1972). During cool/moist nights, plants create droplets of guttation fluid on the hydathodes which are drawn back into the vascular system as the day warms; thereby providing an ideal entry route for bacteria (Curtis 1943). Guttation fluid contains minerals, carbohydrates, and amino acids, and has a $\mathrm{pH}$ of $\sim 7.0$, making it a model medium for $X$. campestris $\mathrm{pv}$. campestris growth (Slusarenko et al. 2000). Once inside the leaf, the bacteria multiply rapidly secreting an extracellular polysaccharide, xanthan, which can plug the xylem vessels and cause tissue damage (Beattie 2011; Sutton and Williams 1970a). The typical X. campestris pv. campestris yellow V-shaped lesions that originate at the leaf edge and extend inward are caused by bacteria that enter through the hydathodes and move through the xylem causing a blockage of water and nutrients, resulting in chlorosis and blackening of veins (Sutton and Williams 1970b).

$X$. campestris pv. campestris infection can also develop on seedlings from bacteria on and/or within the crucifer seed (Cook et al. 1952a,b; Ryan et al. 2011; Schaad et al. 1980; Starr 1981). The presence of bacteria may not decrease the germination rate but can serve as an inoculum source (Walcott 2003). X. campestris pv. campestris has been found to survive in the xylem of the plant for months until conditions are favorable for growth (Cook et al. 1952a). In addition, plant debris and cruciferous weeds in and around the field have also been implicated as inoculum sources for black rot infections (Alvarez and Lou 1985; Schaad and Dianese 1981; Schaad and White 1974). In a study of cruciferous weeds in California, Ignatov et al. (2007) concluded that bacterial populations isolated from weeds had different genetic properties than those associated with seed infections in cultivated Brassica crops (Ignatov et al. 2007).

A second pathovar, $X$. campestris pv. raphani, was first isolated from radish and turnip and causes leaf spots rather than vascular infections in Brassica spp. (White 1930). The leaf spots are usually more numerous near large leaf veins and can cause total leaf collapse when severe, but do not result in a systemic infection 
(Alvarez et al. 1994; Vicente et al. 2001). Unlike X. campestris pv. campestris, pathovar raphani will enter the stomata of true leaves (Cook et al. 1952a; Hugouvieux et al. 1998; Shaw and Kado 1988). Both pathovars are often found on the same plant in natural field infections, which further complicates diagnosis (Chen et al. 1994).

The objectives of this paper were to (i) understand the role of introduced and overwintering isolates in annual black rot outbreaks in New York, (ii) identify likely inoculum sources, (iii) characterize the diversity among pathogenic $X$. campestris pathovars, and (iv) determine the relative importance of vascular versus leaf spotting isolates in the population. We hypothesize that if overwintering isolates are the primary source of inoculum in New York, those haplotypes should persist for at least 2 years. If novel haplotypes are appearing every year, it would suggest that isolates are arriving from external sources (i.e., seed or transplants) and overwintering isolates are not the primary source of inoculum. Here we report the results of pathogenicity and fingerprinting analyses used to differentiate isolates collected over 10 years throughout New York State.

\section{MATERIALS AND METHODS}

Isolate collection. Bacteria were isolated from symptomatic cabbage (Brassica oleracea), broccoli (B. oleracea var. botrytis), Brussels sprouts (B. oleracea var. gemmifera), kale (B. oleracea var. viridis), and cauliflower (B. oleracea var. botrytis) leaves that were collected from greenhouses, seed beds, fields, and winter storage facilities from 2004 to 2013. A total of 154 X. campestris isolates were obtained from the Eastern United States with the majority being collected from New York State $(n=140)$, and the remaining isolates from Pennsylvania $(n=1)$, Michigan $(n=6)$, Georgia $(n=6)$, and Florida $(n=1)$. Since $91 \%$ of the isolates are from New York, the $X$. campestris isolates will be referred to as the New York population.

Tissue was excised from symptomatic leaves, surface sterilized with $0.6 \% \mathrm{NaOCl}$ for $3 \mathrm{~min}$, ground with sterile water using a mortar and pestle, plated onto King's B medium (King et al. 1954), and grown at $28^{\circ} \mathrm{C}$ for 24 to $48 \mathrm{~h}$. Cultures that morphologically appeared to be Xanthomonas and did not fluoresce on King's B medium were cultured on YDC (Wilson et al. 1967) medium to check for yellow mucoid growth (typical of Xanthomonas species) and also cultured on Xanthomonas semiselective SM medium (Chun and Alvarez 1983).

Multilocus sequence analysis (MLSA) and sequence analysis of $X$. campestris. Individual $X$. campestris colony forming units (CFUs) were grown in nutrient broth at $27^{\circ} \mathrm{C}$ with shaking at $160 \mathrm{rpm}$ for $18 \mathrm{~h}$. Genomic DNA was subsequently extracted using the MasterPure DNA purification kit (Epicentre, Madison, WI) according to the manufacturer's instructions. All DNA was quantified with a Nanodrop ND-1000 (Wilmington, DE). MLSA for $X$. campestris was conducted using the previously described primers that amplify seven housekeeping genes-atpD (ATP synthase $\beta$ chain), dnaK (heat shock protein 70), efP (elongation factor P), $g \ln A$ (glutamine synthetase), $g y r B$ (gyrase subunit $\beta$ ), $r p o D$ (RNA polymerase sigma-70 factor), and tpiA (triosephosphate isomerase) - and a single transmembrane protein-fyuA (TonBdependent receptor) (Fargier et al. 2011). The eight loci were analyzed for each isolate using total extracted DNA and genespecific polymerase chain reaction (PCR). Amplification was performed in a C1000 Touch Thermal Cycler (Bio-Rad Laboratories, Inc., Hercules, CA) using EmeraldAmp GT PCR Master Mix (Takara Bio Inc., Otsu, Shiga, Japan). Extracted total DNA was used at 50 to $100 \mathrm{ng}$ per reaction with $10 \mu \mathrm{M}$ each of forward and reverse primers. PCR was performed in $25 \mu \mathrm{l}$ reactions following the previously described protocol (Fargier et al. 2011). PCR products were purified with an ExoSAP (Exonuclease I-Shrimp Alkaline Phosphatase) protocol (New England Biolabs, Ipswich, MA), and the cleaned PCR amplicons were sequenced in both directions on a 3730XL DNA Analyzer (Applied Biosystems) at the Cornell University Life Sciences Core Laboratories Center with the aforementioned PCR amplification primer sets (Fargier et al. 2011).
Raw sequences for each of the eight genes in the MLSA scheme for all 154 isolates were viewed, manually edited according to peak quality, and aligned with Muscle in MEGA 6.06 (Tamura et al. 2013) on an individual gene basis or concatenated. Consensus sequences were used to generate maximum-likelihood (ML) trees based on the Tamura-Nei model (Tamura and Nei 1993) of MEGA 6.06 using all sites with bootstrapping repetitions of 1,000 . Sequences from X. campestris pv. campestris ATCC33913, X. campestris pv. raphani $756 \mathrm{C}$, and $X$. campestris pv. vesicatoria $85-10$ were used as references and an outgroup, respectively (Bogdanove et al. 2011; da Silva et al. 2002; Thieme et al. 2005). Discriminatory power was calculated using a web-based discriminatory power calculator (http: //insilico.ehu.es/mini_tools/discriminatory_power/index.php). Haplotypes were considered unique if the sequence differed by a single nucleotide (Tancos et al. 2015; Wicker et al. 2012). Additionally, the concatenated sequences (eight loci) from 15 previously published $X$. campestris pv. campestris and three $X$. campestris pv. raphani isolates, each representing unique haplotypes $(n=18)$, were compared with the shortened aligned sequences $(4,486$ nucleotides) of the New York haplotypes $(n=64)$ (Fargier et al. 2011). New York haplotypes sequences had to be shortened in order to allow for concatenated sequences from both studies to be compared since different sequencing primers were used in each study.

To provide orthologous support for identified phylogenetic groupings, genetic differentiation among haplotypes was assessed with discriminant analysis of principal components (DAPC) using the adegenet package in R (Jombart 2008). This method maximizes variation between predefined groups, and minimizes within group variance in data transformed by principal component analysis (Jombart et al. 2010). Genotypes were converted to dummy coding $(\mathrm{A}=1, \mathrm{G}=2, \mathrm{C}=3, \mathrm{~T}=4,-=5)$ and variant sites were subsequently converted into a genind object in $\mathrm{R}$ (Jombart 2008). Groups were defined using the $K$-means clustering method in adegenet $(k=3)$, as three clusters best described the data. The a-score optimization function in adegenet was used to determine the optimal number of principal components (PCs) to include in the DAPC $(n=2)$ using the New York data set, representing 49.4 and $28.53 \%$ of the total variance for New York and total isolates, respectively.

Inoculation test for pathogenicity. Two cultivars of cabbage (B. oleracea 'Fresco' and 'Gonzales') susceptible to X. campestris pv. campestris and $X$. campestris pv. raphani were grown in the greenhouse with a $16-\mathrm{h}$ photoperiod at $24^{\circ} \mathrm{C}$. Cabbage seedlings were inoculated at the three true-leaf stage. Each field isolate was grown on YDC medium for 24 to $48 \mathrm{~h}$ at $28^{\circ} \mathrm{C}$. A sterile pin dipped into the bacterial culture was pricked into the outer margin of one leaf eight times and into the petiole and midrib of a second true leaf on the same plant (Vicente et al. 1998). The third leaf of each plant was left uninoculated. Control plants were inoculated with known isolates of $X$. campestris pv. campestris, $X$. campestris pv. raphani, or a sterile pin. Two plants per isolate were inoculated and symptoms were scored visually at 14 days postinoculation. Plants were scored as having no reaction, a typical black rot symptomatic V-shaped yellowto-brown lesion along the leaf margin, or a necrotic spot reaction. This test was repeated twice for each isolate.

Genomic fingerprinting using BOX-A1R repetitive elementpolymerase chain reaction (Rep-PCR). A fingerprint was generated for each isolate collected between 2004 and 2008 using the BOX-A1R primer following a previously described protocol (Louws et al. 1994) with a PTC-100 Peltier thermal cycler (MJ Research, Waltham, MA). Bacterial cells were grown overnight in nutrient broth, the $\mathrm{OD}_{600}$ adjusted to 0.1 , and $12 \mu \mathrm{l}$ was added to the PCR mix (Versalovic et al. 1994). To streamline Rep-PCR, 50 to $100 \mathrm{ng}$ of genomic DNA isolated with the MasterPure DNA purification kit (Epicentre, Madison, WI) (as described above) was used during 2007 to 2008 . The PCR program was $95^{\circ} \mathrm{C}$ for $7 \mathrm{~min}$, and then 35 cycles of $95^{\circ} \mathrm{C}$ for $1 \mathrm{~min}, 53^{\circ} \mathrm{C}$ for $1 \mathrm{~min}, 65^{\circ} \mathrm{C}$ for $8 \mathrm{~min}$ followed by a final extension step at $65^{\circ} \mathrm{C}$ for $8 \mathrm{~min}$ and held at $10^{\circ} \mathrm{C}$. The PCR amplicons $(8 \mu \mathrm{l})$ were loaded onto a $1.5 \%$ agarose gel using 
$0.5 \times \mathrm{TAE}$ buffer and run at $4^{\circ} \mathrm{C}$ for $18 \mathrm{~h}$ at $67 \mathrm{~V}$ (de Bruijn et al. 1996).

Enzyme-linked immunosorbent assay (ELISA) antigen test. ELISA analysis was performed using the Agdia (Elkhart, IN) bacterial reagent sets to differentiate $X$. campestris pv. campestris and $X$. campestris pv. raphani (syn. X. campestris pv. armoraciae) following the manufacturer's protocol. The two isolates with fully sequenced genomes, X. campestris pv. campestris strain 8004 (NCBI ID 314565) and X. campestris pv. campestris strain ATCC 33913, were used as positive controls. Isolate Xca 071 was used as the $X$. campestris pv. raphani positive control. Pseudomonas syringae pv. tomato and coating buffer alone were included as negative controls. Results were recorded for each isolate using visual assessment and confirmed with a microplate reader (Beckman Coulter Inc., Brea, CA). Each ELISA test was performed in duplicate and repeated at least twice for each isolate. The ELISA kit was later discontinued so no isolates after 2008 were tested.

\section{RESULTS}

A total of $154 X$. campestris isolates were collected over 10 years from grower fields or transplant production facilities. Isolates were evaluated with MLSA and a pathogenicity assay, and a subset were also evaluated with Rep-PCR using the BOX-A1R primer, and polyclonal antibodies (ELISA). A complete listing of the results for each isolate can be found in Supplementary Table S1.

MLSA analyses for $X$. campestris. In accordance with Fargier et al. (2011), all eight loci utilized in the MLSA scheme were highly polymorphic with $r p o D$ having the most polymorphic sites at 72, and efP having the least at 10 (Table 1, Supplementary Table S2). Housekeeping genes rpoD and tpiA showed the greatest amount of variation with $7.13 \%$ and $5.47 \%$ of sites being polymorphic in each gene, respectively (Table 1). Sequence variation was approximately 3 to $4 \%$ for the remaining genes. No gaps or insertions were present in any of the sequenced genes. Concatenation of the eight loci could resolve the $154 \mathrm{X}$. campestris isolates into 64 haplotypes with a discriminatory power of 0.967 (Table 1). Of the 64 haplotypes,
41 haplotypes were associated with a single isolate. The most numerous haplotype $(\mathrm{H})$ was $\mathrm{H} 22(n=18)$, which was continually isolated over a period of years from 2006 to 2007 and from 2009 to 2013 (Table 2).

Phylogenetic analyses using the maximum likelihood method demonstrated that the New York $X$. campestris isolates were comprised of two distinct crucifer-infecting pathovars including the following: $X$. campestris pv. campestris $(n=131)$ and $X$. campestris pv. raphani $(n=23)$ (Table 2, Fig. 1). Furthermore, the phylogenetic analysis demonstrated that two subgroups were present within the New York $X$. campestris pv. campestris population (XCC group A and B) with $X$. campestris pv. campestris group B diverging from the single $X$. campestris pv. raphani cluster (Fig. 1). The majority of New York $X$. campestris pv. campestris isolates belonged to group A $(n=103)$ with the remaining isolates in group $\mathrm{B}(n=27)$ or a singleton (H34, isolate 0682). No absolute associations with geographical origin, year, host, or symptoms could be observed between the two $X$. campestris pv. campestris groups. The 131 $X$. campestris pv. campestris isolates alone could be broken into 51 haplotypes with a discriminatory power of 0.956 when the eight loci were concatenated (Table 1).

Twenty-three $X$. campestris isolates were determined to be $X$. campestris pv. raphani based upon sequence data and pathogenicity assays (Tables 1 and 2). As opposed to the $X$. campestris pv. campestris isolates, housekeeping genes tpiA and dnaK showed the greatest amount of variation with 3.70 and $3.38 \%$ of sites being polymorphic in each gene within $X$. campestris pv. raphani, respectively (Table 1 ). When the eight loci were concatenated, the $23 X$. campestris pv. raphani isolates could be separated into 13 haplotypes with a discriminatory power of 0.921 with the most numerous haplotype being $\mathrm{H} 12(n=5)$ and nine haplotypes representing single isolates.

To infer associations and diversity among $X$. campestris between this study and previously published results, $18 X$. campestris isolates (comprising of $15 \mathrm{X}$. campestris pv. campestris and three $X$. campestris pv. raphani isolates) that were collected from Europe, Australia, Africa, and North and South America (Fargier et al. 2011)

TABLE 1. Genetic variation in Xanthomonas campestris isolates determined from multilocus sequence analysis

\begin{tabular}{|c|c|c|c|c|c|}
\hline Gene & Sequenced fragment (bp) & $\begin{array}{c}\text { No. of isolates } \\
\text { sequenced }\end{array}$ & No. of haplotypes & $\begin{array}{c}\text { No. (\%) of polymorphic } \\
\text { sites }\end{array}$ & $\begin{array}{c}\text { Discriminatory } \\
\text { power }\end{array}$ \\
\hline \multicolumn{6}{|c|}{$X$. campestris } \\
\hline$a t p D$ & 767 & 154 & 13 & $30(3.91 \%)$ & 0.860 \\
\hline dnaK & 711 & 154 & 8 & $25(3.52 \%)$ & 0.544 \\
\hline efP & 419 & 154 & 8 & $10(2.39 \%)$ & 0.742 \\
\hline fyuA & 761 & 154 & 12 & $26(3.42 \%)$ & 0.704 \\
\hline$g \ln A$ & 789 & 154 & 13 & $26(3.30 \%)$ & 0.719 \\
\hline gyrB & 831 & 154 & 10 & $27(3.25 \%)$ & 0.710 \\
\hline rpoD & 1,010 & 154 & 15 & $72(7.13 \%)$ & 0.788 \\
\hline tpiA & 676 & 154 & 15 & $37(5.47 \%)$ & 0.855 \\
\hline Concat. & 5,964 & 154 & 64 & $253(4.24 \%)$ & 0.967 \\
\hline \multicolumn{6}{|c|}{$X$. campestris pv. campestris } \\
\hline $\operatorname{atpD}$ & 767 & 131 & 8 & $24(3.13 \%)$ & 0.812 \\
\hline $\operatorname{dnaK}$ & 711 & 131 & 4 & $6(0.844 \%)$ & 0.470 \\
\hline efP & 419 & 131 & 5 & $7(1.67 \%)$ & 0.654 \\
\hline fyuA & 761 & 131 & 7 & $19(2.50 \%)$ & 0.601 \\
\hline$g \ln A$ & 789 & 131 & 8 & $13(1.65 \%)$ & 0.617 \\
\hline gyrB & 831 & 131 & 7 & $17(2.05 \%)$ & 0.625 \\
\hline rpoD & 1,010 & 131 & 11 & $61(6.04 \%)$ & 0.712 \\
\hline tpiA & 676 & 131 & 11 & $22(3.25 \%)$ & 0.806 \\
\hline Concat. & 5,964 & 131 & 51 & $169(2.83 \%)$ & 0.956 \\
\hline \multicolumn{6}{|c|}{ X. campestris pv. raphani } \\
\hline $\operatorname{atpD}$ & 767 & 23 & 5 & $22(2.87 \%)$ & 0.771 \\
\hline $\operatorname{dnaK}$ & 711 & 23 & 5 & $24(3.38 \%)$ & 0.771 \\
\hline efP & 419 & 23 & 4 & $7(1.67 \%)$ & 0.593 \\
\hline fyuA & 761 & 23 & 5 & $12(1.58 \%)$ & 0.609 \\
\hline$g \ln A$ & 789 & 23 & 5 & $19(2.41 \%)$ & 0.771 \\
\hline gyrB & 831 & 23 & 5 & $18(2.17 \%)$ & 0.557 \\
\hline rpoD & 1,010 & 23 & 5 & $26(2.57 \%)$ & 0.806 \\
\hline tpiA & 676 & 23 & 5 & $25(3.70 \%)$ & 0.771 \\
\hline Concat. & 5,964 & 23 & 13 & $153(2.56 \%)$ & 0.921 \\
\hline
\end{tabular}


were compared with the 64 New York haplotypes (Fig. 2). Phylogenetics demonstrated that the haplotypes from the separate populations were intermixed with no distinct clustering (Fig. 2). The Fargier et al. (2011) isolates similarly clustered among the two distinct $X$. campestris pv. campestris subgroups (XCC group A and B) and the $X$. campestris pv. raphani cluster. In addition, $X$. campestris pv. campestris isolate 1711 (collected from France) had high sequence identity to the single New York $X$. campestris pv.

TABLE 2. Diversity observed among Xanthomonas campestris isolates based on phylogenetic subgroup, MLSA haplotype, symptoms observed during pathogenicity assays, and years collected

\begin{tabular}{|c|c|c|c|c|}
\hline Phylogenetic subgroup ${ }^{a}$ & Conc. haplotype & No. of isolates & Symptoms ${ }^{\mathrm{b}}$ & Years isolated \\
\hline \multicolumn{5}{|c|}{ X. campestris pv. campestris } \\
\hline A & $\mathrm{H} 3$ & 13 & $\mathrm{~V}$ & $2004,2005,2007,2010,2011,2012$ \\
\hline A & $\mathrm{H} 21$ & 1 & $\mathrm{~V}$ & 2006 \\
\hline A & $\mathrm{H} 22$ & 18 & $\mathrm{~V}$ & 2006, 2007, 2009, 2010, 2011, 2012, 2013 \\
\hline A & $\mathrm{H} 23$ & 1 & $\mathrm{~V}$ & 2006 \\
\hline A & $\mathrm{H} 30$ & 2 & $\mathrm{~V}$ & 2006 \\
\hline A & $\mathrm{H} 31$ & 6 & $\mathrm{~V}$ & 2004, 2006, 2007, 2013 \\
\hline A & $\mathrm{H} 32$ & 1 & $\mathrm{~V}$ & 2006 \\
\hline A & H35 & 1 & $\mathrm{~V}$ & 2006 \\
\hline A & H37 & 7 & $\mathrm{~V}$ & 2008, 2009 \\
\hline A & $\mathrm{H} 38$ & 1 & $\mathrm{~V}$ & 2008 \\
\hline A & H39 & 1 & $\mathrm{~V}$ & 2008 \\
\hline A & $\mathrm{H} 45$ & 7 & $\mathrm{~V}$ & 2009, 2011 \\
\hline A & $\mathrm{H} 46$ & 3 & $\mathrm{~V}$ & 2009, 2011 \\
\hline A & $\mathrm{H} 48$ & 2 & $\mathrm{~V}$ & 2009 \\
\hline A & $\mathrm{H} 49$ & 1 & $\mathrm{~V}$ & 2009 \\
\hline A & $\mathrm{H} 50$ & 1 & $\mathrm{~V}$ & 2009 \\
\hline A & H51 & 1 & $\mathrm{~V}$ & 2010 \\
\hline A & H52 & 1 & $\mathrm{~V}$ & 2010 \\
\hline A & H53 & 1 & $\mathrm{~V}$ & 2010 \\
\hline A & H54 & 1 & $\mathrm{~V}$ & 2010 \\
\hline A & H55 & 1 & $\mathrm{~V}$ & 2010 \\
\hline A & H56 & 1 & $\mathrm{~V}$ & 2010 \\
\hline A & $\mathrm{H} 58$ & 1 & $\mathrm{~V}$ & 2011 \\
\hline A & H59 & 1 & $\mathrm{~V}$ & 2011 \\
\hline A & H60 & 1 & $\mathrm{~V}$ & 2012 \\
\hline B & $\mathrm{H} 26$ & 2 & $\mathrm{~V}$ & 2006 \\
\hline B & $\mathrm{H} 28$ & 1 & $\mathrm{~V}$ & 2006 \\
\hline B & $\mathrm{H} 29$ & 2 & $\mathrm{~V}$ & 2006,2008 \\
\hline B & H57 & 1 & $\mathrm{~V}$ & 2011 \\
\hline B & H62 & 1 & $\mathrm{~V}$ & 2013 \\
\hline Singleton & H34 & 1 & $\mathrm{~V}$ & 2006 \\
\hline \multicolumn{5}{|l|}{$X$. campestris pv. raphani } \\
\hline $\mathrm{C}$ & $\mathrm{H} 7$ & 1 & NS & 2005 \\
\hline $\mathrm{C}$ & $\mathrm{H} 8$ & 2 & NS & 2005, 2009 \\
\hline $\mathrm{C}$ & $\mathrm{H} 10$ & 1 & NS & 2005 \\
\hline $\mathrm{C}$ & H11 & 1 & NS & 2005 \\
\hline $\mathrm{C}$ & $\mathrm{H} 12$ & 5 & NS & $2005,2006,2007$ \\
\hline $\mathrm{C}$ & H13 & 3 & NS & $2005,2007,2009$ \\
\hline $\mathrm{C}$ & H14 & 1 & NS & 2005 \\
\hline $\mathrm{C}$ & H17 & 1 & NS & 2005 \\
\hline $\mathrm{C}$ & H18 & 1 & NS & 2006 \\
\hline $\mathrm{C}$ & $\mathrm{H} 20$ & 1 & NS & 2006 \\
\hline $\mathrm{C}$ & H33 & 1 & NS & 2009 \\
\hline $\mathrm{C}$ & H36 & 4 & NS & 2007, 2009, 2012, 2013 \\
\hline $\mathrm{C}$ & $\mathrm{H} 47$ & 1 & NS & 2009 \\
\hline
\end{tabular}

a The X. campestris pv. campestris New York population could be divided into two subgroups (XCC A and XCC B) and a singleton, but the X. campestris pv. raphani New York population remained in a single group (XCR C).

${ }^{\mathrm{b}}$ Characteristic symptoms observed from greenhouse pathogenicity assays. The two symptoms observed included: V-shaped lesions on the margins of leaves (V) or necrotic spots covering the leaves (NS). 
campestris isolate $0682(\mathrm{H} 34)$, which was distinct from both $X$. campestris pv. campestris subgroups A and B (Figs. 1 and 2). Surprisingly, several New York X. campestris haplotypes had high sequence identity to the Fargier et al. (2011) isolates with zero single nucleotide polymorphisms (SNPs) detected, even though isolates were collected decades apart from various countries (Table 3 ).

The DAPC analysis was consistent with the phylogenetic analyses for both New York (Fig. 1B) and combined haplotypes,
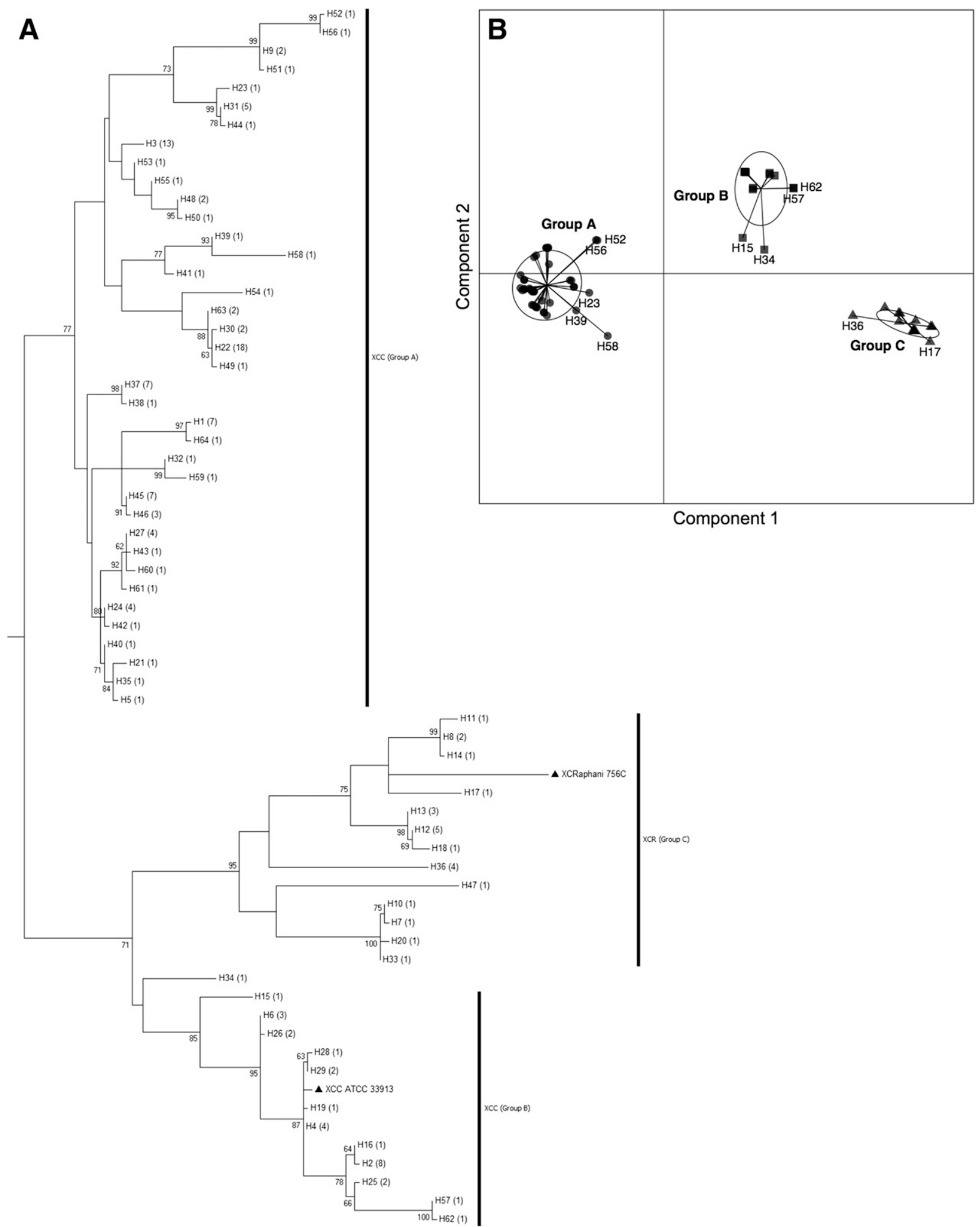

Fig. 1. A, Maximum likelihood (ML) phylogenetic tree for the concatenated genes $(5,964$ nucleotides)—atpD, dnaK, efP, glnA, gyrB, rpoD, tpiA, and fyuA—for New York Xanthomonas campestris haplotypes $(n=64)$ and reference strains X. campestris pv. campestris ATCC 33913 and X. campestris pv. raphani $756 C$. The ML tree is rooted against reference strain X. campestris pv. vesicatoria 85-10 (root is not shown). Reference strains are designated with black triangles. The number of isolates per haplotype group $(\mathrm{H})$ is displayed in parentheses. Bootstrap values are shown at the nodes if greater than $50 \%$. The tree is drawn to scale, with branch lengths measured in the number of substitutions per site (Tamura et al. 2013). B, The same data set as A, plotted on the first two principal components of the DAPC with groups represented as inertia ellipses. Different shapes represent the three phylogenetic subgroups $(\mathrm{A}=$ circle; $\mathrm{B}=$ square; and $\mathrm{C}=$ triangle $)$. 
showing clear differentiation between the three groups. The two haplotypes, $\mathrm{H} 34$ and 1711, which were distinct from subgroups A and $B$ in the phylogenetic analysis, clustered with group B in the DAPC. This is not surprising in that these haplotypes were most closely related to group B haplotypes in the phylogeny.

All MLSA haplotype gene sequences were deposited in GenBank (accession no.: atpD [KR922987 to KR922999], dnaK [KR922979 to KR922986], efP [KR922971 to KR922978], fyuA [KR922959 to KR922970], $g \ln A$ [KR922946 to KR922958], gyrB [KR922936 to KR922945], rpoD [KR922921 to KR922935], and tpiA [KR922906 to KR922920]).

Pathogenicity assay. All of the 154 collected isolates caused either V-shaped lesions or leaf spotting when inoculated into young cabbage plants in the greenhouse (Table 2). The majority of isolates tested, $85 \%(n=131)$, caused typical V-shaped lesions in the inoculated greenhouse cabbage plants and the remaining $15 \%(n=$ 23) caused leaf spotting (Table 2). Twenty-one of the 35 isolates collected from transplants in early spring caused leaf spotting reactions ( $X$. campestris pv. raphani), while only two field isolates were found to cause leaf spotting indicative of $X$. campestris pv. raphani. These results were consistent between replications of the inoculations.

BOX-A1R PCR fingerprinting. A total of 15 BOX-A1R patterns-1 $(n=4), 2(n=15), 3(n=8), 4(n=3), 5(n=6), 6(n=8)$, $7(n=2), 8(n=2), 9(n=12), 10(n=21), 11(n=1), 12(n=7), 13$ $(n=2), 14(n=3)$, and $15(n=1)$-were observed among the 95 isolates of $X$. campestris collected between 2004 and 2008 that were tested using this method. There was no correlation between BOX-A1R patterns and their spatial distribution, and very little fingerprint overlap from year-to-year except for one farm where the same fingerprint (BOX-A1R pattern 2) was isolated over a five year period (isolates 0450, 0659, 0660, 0792, and 08306). Interestingly, BOX-A1R pattern 1 was characterized from several isolates in New York and from seed of the same variety obtained from a seed testing facility that year (isolates 0407, 0455, 0473, and 0499E3).

ELISA antigen assay. The serological data collected from five years of isolates showed $86 \%(n=91)$ of the 106 isolates tested reacted only with the $X$. campestris pv. campestris antigen, while $12 \%(n=13)$ were positive only with the $X$. campestris pv. raphani antigen. Two isolates reacted with both antigens. The pathogenicity assay results did not always correlate with the ELISA results. Based on ELISA, 24 isolates did not show the corresponding pathogenicity symptom typical of their pathovar. Results were consistent both within and between replications.

\section{DISCUSSION}

This study has enabled a better understanding of the population diversity of $X$. campestris isolates associated with symptomatic cruciferous crops, their frequency, persistence, and distribution statewide. Over the previous 10 years, $154 \mathrm{X}$. campestris isolates were collected and characterized from symptomatic seedlings, field plants, and stored cabbage heads. Because $X$. campestris pv. campestris and $X$. campestris pv. raphani are both present in New York, it was not surprising to find both pathogens in our survey. Interestingly, $X$. campestris pv. raphani was relatively uncommon in the field, but prevalent with transplants from production greenhouses. This distinction could be explained by the selection process of diseased field tissue (extension agents/growers would send tissue that had characteristic V-shaped lesions) and/or by that fact that $X$. campestris pv. raphani proliferates better in warm/humid environments such as greenhouses (Zhao et al. 2000).

The two pathovars were differentiated in greenhouse pathogenicity tests because $X$. campestris pv. campestris was systemic, forming $\mathrm{V}$-shaped lesions with vein blackening, while $X$. campestris pv. raphani caused localized necrotic spots. For the majority of New
York isolates, a $X$. campestris pv. campestris positive ELISA test, which were performed the first 6 years, correlated with V-shaped lesions when tested on cabbage in the greenhouse, but systemic isolates were not always characterized as pv. campestris nor were necrotic spot-producing isolates always characterized as pv. raphani. Similar results were previously reported demonstrating the antibodies apparent lack of specificity between pathovars (Alvarez and Lou 1985; Alvarez et al. 1994). This could be explained by the fact that vascular and nonvascular Xanthomonads appear to have few differences in gene content even though they display differing tissue specificity; and symptom expression could be modified by $\mathrm{pH}$, temperature, and other environmental conditions (Bogdanove et al. 2011; Chen et al. 1994; He et al. 2007).

The MLSA approach to genotype $X$. campestris isolates that infected Brassica vegetables provided an excellent view of the $X$. campestris population within New York State, and how these strains are spreading both spatially and temporally. X. campestris pv. campestris can be disseminated through infected seed and/or transplants, thereby, being a major concern to both growers and seed producers. Many Brassica vegetable growers in New York (and other states) outsource the growing and maintenance of seedlings to greenhouse transplant production facilities that are both in- and outof-state. When transplants are ready for direct planting they are then shipped to their respective growers. In our study, infected transplants were received from greenhouse transplant production facilities in three states.

Interestingly, one of the greenhouse transplant facilities had several MLSA haplotypes of $X$. campestris pv. raphani $(n=10)$ present throughout the years. In 2005, seven different haplotypes of $X$. campestris pv. raphani were present at the transplant facility; however, many of those haplotypes were lost in the following years except for haplotype H12 (persisted from 2005 to 2007) and haplotypes H13 and H8, which both persisted until 2009. Subsequently, H36 became the prominent haplotype from 2007 to 2013. This haplotype could have survived on reused flats, benches or elsewhere in the environment of the facility, or could have been reintroduced on contaminated seed during that seven year period. None of the haplotypes that persisted at the facility were later isolated from fields in New York or the surrounding states.

$X$. campestris pv. campestris haplotype $\mathrm{H} 45$ was isolated from a specific cabbage variety in two greenhouse transplant production facilities located in disparate states in 2009. The simultaneous isolation of an identical haplotype from different greenhouse transplant production facilities (in different states) in the same year suggests that the hybrid seed could have been contaminated, thereby, spreading this unique haplotype to growers across several states. Haplotype H45 was later isolated from New York fields in 2011. Evidence for isolates moving into fields from infected seed was further documented with isolates characterized with the haplotype $\mathrm{H} 1$ and BOX-A1R pattern 1 (isolates 0407, 0455, and 0473), which were collected from three different New York counties in 2004 from the same cabbage variety. The identical MLSA haplotype and BOX-A1R pattern was also observed in an isolate collected from seed of the same cabbage variety obtained from a seed testing facility that year (isolate 0499E3). The haplotype was again isolated in New York in 2011 and 2013. The initial introduction event in 2004 appears to be seed-associated, however, the re-isolation of haplotype $\mathrm{H} 1$ in 2011 and 2013 could have been due to overwintering or a reintroduction event.

Two distinct crucifer-infecting pathovars, $X$. campestris pv. campestris and $X$. campestris pv. raphani, were detected and differentiated by MLSA throughout our study; however, within $X$. campestris pv. campestris, two phylogenetically distinct subgroups (based on MLSA data) persisted throughout the years with subgroup B being more genetically similar to $X$. campestris pv. raphani than $X$. campestris pv. campestris subgroup A. No differences in symptoms, 
disease progression or host range were observed between these two subgroups of $X$. campestris pv. campestris. The majority of $X$. campestris pv. campestris isolates clustered in subgroup A, in which an isolate was collected every year. No X. campestris pv. campestris isolates from subgroup B were detected in 2009, 2010, or 2012. Interestingly, a New York $X$. campestris pv. campestris isolate with the unique haplotype $\mathrm{H} 34$ clustered as a singleton between $X$. campestris pv. campestris subgroup B and $X$. campestris pv. raphani.

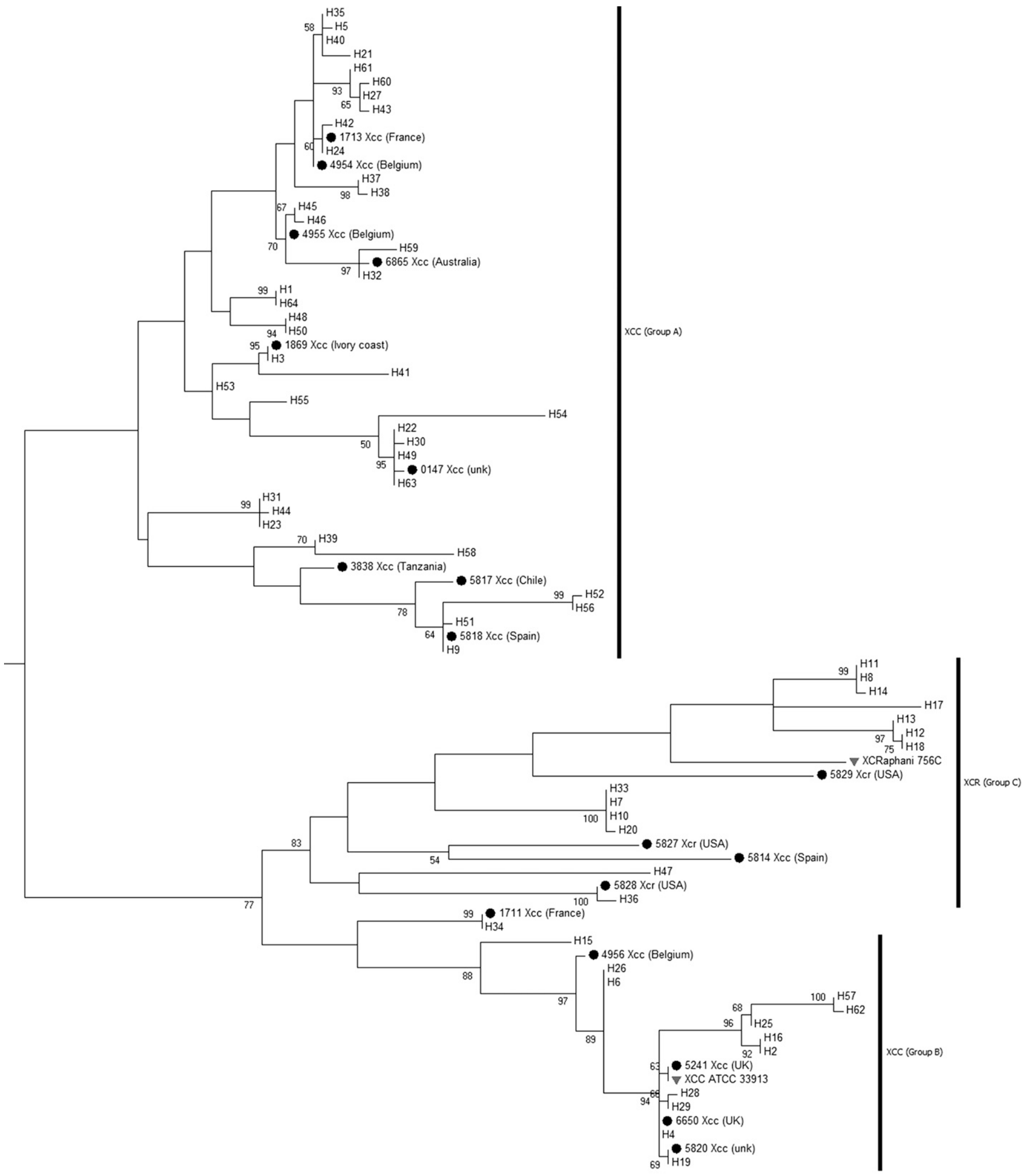

Fig. 2. Maximum likelihood (ML) phylogenetic tree for the shortened concatenated genes (4,486 nucleotides)—atpD, dnaK, efP, glnA, gyrB, rpoD, tpiA, and fyuA-for unique New York Xanthomonas campestris haplotypes $(n=64)$, previously studied $X$. campestris sequence types $(n=18)$, and reference strains $X$. campestris pv. campestris ATCC33913 and X. campestris pv. raphani 756C. The ML tree is rooted against reference strain X. campestris pv. vesicatoria 85-10 (root is not shown). Reference strains are designated with black triangles, while unique sequence types from Fargier et al. (2011) are designated with black dots. Haplotype number and/or strain number are indicated with country of isolation in parentheses. Bootstrap values are shown at the nodes if greater than 50\%. The tree is drawn to scale, with branch lengths measured in the number of substitutions per site (Tamura et al. 2013). 
Two phylogenetically distinct subgroups of $X$. campestris $\mathrm{pv}$. campestris have been identified in smaller populations of globally isolated X. campestris isolates (Alvarez et al. 1994; Fargier et al. 2011; Tsygankova et al. 2004). When several X. campestris isolates from the Fargier et al. (2011) study were included in our analysis, the majority of the $X$. campestris pv. campestris isolates (collected in Europe, Africa, and North and South America) clustered into subgroup A, while few isolates clustered into subgroup B (Fargier et al. 2011). However, evolutionary inferences between the $X$. campestris pv. campestris subgroups and $X$. campestris $\mathrm{pv}$. raphani should be approached with caution when using MLSA data alone (Baltrus et al. 2014). Future work with isolates from each of the $X$. campestris pv. campestris subgroups using whole-genome sequencing should be implemented to identify relationships between the subgroups and their similarity to X. campestris pv. raphani. Even though they are phylogenetically similar, $X$. campestris $\mathrm{pv}$. raphani and $X$. campestris pv. campestris have very distinct infection mechanisms (nonvascular versus vascular). Bogdanove et al. (2011) compared the two complete genomes of nonvascular (X. campestris pv. raphani) and (X. oryzae pv. oryzicola). They found that adaptations at the level of gene content account for host specificity and subtler adaptations at the level of amino acid or noncoding regulatory nucleotide sequences determine tissue specificity (Bogdanove et al. 2011).

MLSA haplotypes of New York isolates do not appear to be unique as no distinct clustering was present when the New York $X$. campestris haplotypes were compared with the globally collected haplotypes (Fargier et al. 2011). The global population of $X$. campestris pv. campestris appears to be very homogenous with dominant haplotypes persisting for extended periods. For example, numerous $X$. campestris pv. campestris haplotypes collected from 1958 to 2001 across Europe, Africa, and Australia had one or zero SNPs (between the eight concatenated housekeeping genes) when compared with New York strains collected between 2004 to 2013 (Table 3). More genetic variation appeared to exist between New York haplotypes than between globally collected strains isolated approximately 50 years ago. Granted, we are unable to say that the strains present in the mid-twentieth century are identical to the strains being recovered from grower's fields in New York, but it appears that several dominant haplotypes are persisting and being globally-disseminated.

An absolute correlation did not exist between MLSA and BOXA1R for diverse isolates of $X$. campestris; however, associations were common. Both MLSA and BOX-A1R provide complementary approaches to fingerprinting isolates based on either SNPs (present within the housekeeping genes) or differences in the spacing of repetitive sequences (dispersed throughout the genome), respectively. The utilization of both methods in combination provided greater differentiating capabilities, but as sequencing costs became lower and the number of BOX-A1R patterns increased it became clear that MLSA would be a more effective approach to characterize $X$. campestris populations because of its efficiency, speed, easier interlab reproducibility, and ability to quickly compare global populations (Tancos et al. 2015; Wicker et al. 2012).

Over the course of this study, $15 \mathrm{BOX}-\mathrm{A} 1 \mathrm{R}$ patterns were identified among the subset of $X$. campestris pv. campestris and $X$. campestris pv. raphani isolates collected from 2004 to 2008. There was a wide variation of isolates across New York and new isolates were identified each year. While the rate at which new BOX-A1R patterns develop is unknown, the fact that isolates with the same BOX-A1R pattern (pattern 2) were identified at the same farm for 5 years (isolates 0450 , 0659, 0660, 0792, and 08306) provides important evidence that BOX-A1R patterns are stable over the course of a single season (or even several seasons) in New York. The MLSA data agreed with the aforementioned BOX-A1R pattern by demonstrating that the isolates had nearly identical haplotypes (H31 differed from H44 [isolate 08306] by a single SNP). The isolates persisted on the same farm due to improper seedbed rotations and sanitation. Our BOX-A1R results are similar to what has been observed by others in many parts of the world studying diseases caused by bacterial phytopathogens (Hartung and Civerolo 1987; Norman et al. 2009; Schneider 1996). Studies of $X$. campestris from many countries in Europe, Asia, and Africa found, as we did, that BOX-A1R patterns did not correlate with race type or geographic location, but the technique was valuable for confirming pathogen diversity (Chidamba and Bezuidenhout 2012; Jensen et al. 2010; Lema et al. 2012; Massomo et al. 2003; Mulema et al. 2011; Rouhrazi and Khodakaramian 2014; Singh et al. 2011; Valverde et al. 2007; Zaccardelli et al. 2008).

The data presented here demonstrate that the New York populations of $X$. campestris pv. campestris and $X$. campestris pv. raphani are highly diverse with $64 \%$ of the isolates being unique haplotypes that were represented only once. Conversely, some dominant haplotypes were present for five or more years (haplotypes $\mathrm{H} 3$ and $\mathrm{H} 22$ ) and were collected across New York State. X. campestris pv. campestris is capable of being maintained on the same farm for several years as previously noted; however, the appearance of novel haplotypes each year implies that overwintering of the pathogen is not the primary source of inoculum in New York, but that new haplotypes are being transported into the state each year.

TABLE 3. Sequence similarity compared between Xanthomonas campestris haplotypes collected in New York (present study) and globally (Fargier et al. 2011)

\begin{tabular}{|c|c|c|c|c|c|c|c|c|}
\hline \multicolumn{4}{|c|}{ New York population ${ }^{a}$} & \multicolumn{4}{|c|}{ Global population $^{\mathrm{a}}$} & \multirow[b]{2}{*}{$\begin{array}{l}\text { No. of } \\
\text { SNPs }^{\mathrm{d}}\end{array}$} \\
\hline Haplotypes & Year(s) isolated & Location $^{\mathrm{b}}$ & $\begin{array}{l}\text { No. of } \\
\text { isolates }^{\mathrm{c}}\end{array}$ & Haplotypes & Year(s) isolated & Location $^{b}$ & $\begin{array}{l}\text { No. of } \\
\text { isolates }^{\mathrm{c}}\end{array}$ & \\
\hline \multicolumn{9}{|c|}{ X. campestris pv. campestris } \\
\hline $\mathrm{H} 24$ & 2006, 2008 & NY & 4 & ST16 & 1975,1979 & FR & 3 & 0 \\
\hline $\mathrm{H} 34$ & 2006 & NY & 1 & ST20 & $1958,1967,1975$ & FR, DE & 4 & 0 \\
\hline $\mathrm{H} 3$ & $2004-05,2007,2010-12$ & NY & 13 & ST17 & $1967,1976,1999-00$ & $\mathrm{CI}, \mathrm{FR}, \mathrm{BE}, \mathrm{ES}$ & 9 & 0 \\
\hline $\mathrm{H} 45$ & 2009, 2011 & NY, MI, GA & 7 & ST22 & 1967, 1999 & FR, BE & 2 & 1 \\
\hline $\mathrm{H} 22$ & $2006-07,2009-13$ & NY, PA & 18 & ST1 & unk & unk & 1 & 1 \\
\hline \multicolumn{9}{|c|}{$X$. campestris pv. raphani } \\
\hline $\mathrm{H} 36$ & $2007,2009,2012-13$ & NY & 4 & ST13 & unk & US & 1 & 2 \\
\hline
\end{tabular}

a Subset of unique haplotypes collected from New York (present study) or the Fargier et al. (2011) study and how the haplotypes compare.

b Location where isolates were collected. FR $=$ France, DE $=$ Germany, UK $=$ United Kingdom, CI = Cote d'lvoire (Ivory Coast), BE $=$ Belgium, ES $=$ Spain, $\mathrm{AU}=$ Australia, $\mathrm{US}=$ United States, $\mathrm{NY}=$ New York, $\mathrm{MI}=$ Michigan, $\mathrm{GA}=$ Georgia, unk $=$ unknown .

c The number of isolates that comprise the respective haplotype group.

${ }^{d}$ The number of single nucleotide polymorphisms (SNPs) detected in the eight concatenated housekeeping genes $(4,486$ nucleotides) that differentiate the two haplotype groups (New York population versus global population). 


\section{ACKNOWLEDGMENTS}

We thank the New York Cabbage Research and Development Program for funds for this research, members of the Smart lab for help and advice, and A. J. Brewer for MLSA work. We also thank the cabbage growers, scouts, and extension agents who provided samples for this study.

\section{LITERATURE CITED}

Alvarez, A. M., Benedict, A. A., Mizumoto, C. Y., Hunter, J. E., and Gabriel, D. W. 1994. Serological, pathological, and genetic diversity among strains of Xanthomonas campestris infecting crucifers. Phytopathology 84:1449-1457.

Alvarez, A. M., and Lou, K. 1985. Rapid identification of Xanthomonas campestris pv. campestris by ELISA. Plant Dis. 69:1082-1086.

Baltrus, D. A., Dougherty, K., Beckstrom-Sternberg, S. M., Beckstrom-Sternberg, J. S., and Foster, J. T. 2014. Incongruence between multi-locus sequence analysis (MLSA) and whole-genome-based phylogenies: Pseudomonas syringae pathovar pisi as a cautionary tale. Mol. Plant Pathol. 15:461-465.

Beattie, G. A. 2011. Water relations in the interaction of foliar bacterial pathogens with plants. Annu. Rev. Phytopathol. 49:533-555.

Bogdanove, A. A. J., Koebnik, R., Lu, H., Furutani, A., Angiuoli, S. S. V., Patil, P. P. B., Van Sluys, M. A., Ryan, R. P., Meyer, D. F., Han, S. W., Aparna, G., Rajaram, M., Delcher, A. L., Phillippy, A. M., Puiu, D., Schatz, M. C., Shumway, M., Sommer, D. D., Trapnell, C., Benahmed, F., Dimitrov, G., Madupu, R., Radune, D., Sullivan, S., Jha, G., Ishihara, H., Lee, S. W., Pandey, A., Sharma, V., Sriariyanun, M., Szurek, B., Vera-Cruz, C. M., Dorman, K. S., Ronald, P. C., Verdier, V., Dow, J. M., Sonti, R. V., Tsuge, S., Brendel, V. P., Rabinowicz, P. D., Leach, J. E., White, F. F., and Salzberg, S. L. 2011. Two new complete genome sequences offer insight into host and tissue specificity of plant pathogenic Xanthomonas spp. J. Bacteriol. 193:5450-5464.

Carisse, O., Willman-Desbiens, W., Toussaint, V., and Otis, T. 1998. Preventing Black Rot. CRDH, Agriculture and Agri-Food Canada, Quebec.

Chen, J., Roberts, P. D., and Gabriel, D. W. 1994. Effects of a virulence locus from Xanthomonas campestris 528T on pathovar status and ability to elicit blight symptoms on crucifers. Phytopathology 84:1458-1465.

Chidamba, L., and Bezuidenhout, C. C. 2012. Characterization of Xanthomonas campestris pv. campestris isolates from South Africa using genomic DNA fingerprinting and pathogenicity tests. Eur. J. Plant Pathol. 133:811-818.

Chun, W. C., and Alvarez, A. M. 1983. A starch-methionine medium for isolation of Xanthomonas campestris pv. campestris from plant debris in soil. Plant Dis. 67:632-635.

Cook, A. A., Larson, R. H., and Walker, J. C. 1952a. Relation of the black rot pathogen to cabbage seed. Phytopathology 42:316-320.

Cook, A. A., Walker, J. C., and Larson, R. H. 1952b. Studies on the disease cycle of black rot of crucifers. Phytopathology 42:162-167.

Curtis, L. C. 1943. Deleterious effects of guttation fluids on foliage. Am. J. Bot. 30:778-782.

da Silva, A. C. R., Ferro, J. A., and Reinach, F. C. 2002. Comparison of the genomes of two Xanthomonas pathogens with differing host specificities. Nature 417:459-463.

de Bruijn, F. J., Rademaker, J. L. W., Schneider, M., Rossbach, U., and Louws, J. F. 1996. Rep-PCR genomic fingerprinting of plant-associated bacteria and computer-assisted phylogenic analyses. Pages 497-502 in: 8th International Congress of Molecular Plant-Microbe Interactions. G. Stacey, B. Mullin, and P. Gresshoff, eds. The American Phytopathological Society, St. Paul, MN.

Fargier, E., Saux, M. F.-L., and Manceau, C. 2011. A multilocus sequence analysis of Xanthomonas campestris reveals a complex structure within cruciferattacking pathovars of this species. Syst. Appl. Microbiol. 34:156-165.

Hartung, J. S., and Civerolo, E. L. 1987. Genomic fingerprints of Xanthomonas campestris pv. citri strains from Asia, South America, and Florida. Phytopathology 77:282-285.

He, Y.-Q., Zhang, L., Jiang, B.-L., Zhang, Z.-C., Xu, R.-Q., and Tang, D.-J. 2007. Comparative and functional genomics reveals genetic diversity and determinants of host specificity among reference strains and a large collection of Chinese isolates of the phytopathogen Xanthomonas campestris pv. campestris. Genome Biol. 8:R218.

Hugouvieux, V., Barber, C. E., and Daniels, M. J. 1998. Entry of Xanthomonas campestris pv. campestris into hydathodes of Arabidopsis thaliana leaves: A system for studying early infection events in bacterial pathogenesis. Mol. Plant-Microbe Interact. 11:537-543.

Ignatov, A. N., Sechler, A., Schuenzel, E. L., Agarkova, I., Oliver, B., and Vidaver, A. K. 2007. Genetic diversity in populations of Xanthomonas campestris pv. campestris in cruciferous weeds in Central Coastal California. Phytopathology 97:803-812.

Jensen, B. D., Vicente, J. G., Manandhar, H. K., and Roberts, S. J. 2010. Occurrence and diversity of Xanthomonas campestris pv. campestris in vegetable Brassica fields in Nepal. Plant Dis. 94:298-305.
Jombart, T. 2008. adegenet: A R package for the multivariate analysis of genetic markers. Bioinformatics 24:1403-1405.

Jombart, T., Devillard, S., and Balloux, F. 2010. Discriminant analysis of principal components: A new method for the analysis of genetically structured populations. BMC Genet. 11:94.

King, E. O., Ward, M. K., and Raney, D. R. 1954. Two simple media for the demonstration of pyrocanin and fluorescein. J. Lab. Clin. Med. 44:301-307.

Lema, M., Cartea, M. E., Sotelo, T., Velasco, P., and Soengas, P. 2012. Discrimination of Xanthomonas campestris pv. campestris races among strains from northwestern Spain by Brassica spp. genotypes and rep-PCR. Eur. J. Plant Pathol. 133:159-169.

Louws, F. J., Fulbright, D. W., Stephens, C. T., and Debruijn, F. J. 1994. Specific genomic fingerprints of phytopathogenic Xanthomonas and Pseudomonas pathovars and strains generated with repetitive sequences and PCR. Appl. Environ. Microbiol. 60:2286-2295.

Massomo, S. M. S., Nielsen, H., Mabagala, R. B., Mansfeld-Giese, K., Hockenhull, J., and Mortensen, C. N. 2003. Identification and characterization of Xanthomonas campestris pv. campestris strains from Tanzania by pathogenicity tests, Biolog, rep-PCR and fatty acid methyl ester analysis. Eur. J. Plant Pathol. 109:775-789.

Mulema, J., Vicente, J., Pink, D., Jackson, A., Chacha, D., and Wasilwa, L. 2011. Characterization of isolates that cause black rot of crucifers in East Africa. Eur. J. Plant Pathol. 133:427-438.

Norman, D. J., Zapata, M., Gabriel, D. W., Duan, Y. P., Yuen, J. M. F., and Mangravita-Novo, A. 2009. Genetic diversity and host range variation of Ralstonia solanacerarum strains entering North America. Phytopathology 99:1070-1077.

Rouhrazi, K., and Khodakaramian, G. 2014. Genetic fingerprinting of Iranian Xanthomonas campestris pv. campestris strains inducing black rot disease of crucifers. Eur. J. Plant Pathol. 139:175-184.

Ryan, R. P., Vorholter, F.-J., Potnis, N., Jones, J. B., Van Sluys, M.-A., and Bogdanove, A. J. 2011. Pathogenomics of Xanthomonas: Understanding bacterium-plant interactions. Nat. Rev. Microbiol. 9:344-355.

Schaad, N. C., and Dianese, J. C. 1981. Cruciferous weeds as sources of inoculum of Xanthomonas campestris in black rot of crucifers. Phytopathology 71:1215-1220.

Schaad, N. C., Sitterly, W. R., and Humaydan, H. 1980. Relationship of incidence of seedborne Xanthomonas campestris to black rot of crucifers. Plant Dis. 64:91-92.

Schaad, N. W., and White, W. C. 1974. Survival of Xanthomonas campestris in soil. Phytopathology 64:1518-1520.

Schneider, M. 1996. Rep-PCR mediated genomic fingerprinting of rhizobia and computer-assisted phylogenetic pattern analysis. World J. Microbiol. Biotechnol. 12:163-174.

Shaw, J. J., and Kado, C. I. 1988. Whole plant wound inoculation for consistent reproduction of black rot of crucifers. Phytopathology 78:981-986.

Singh, D., Dhar, S., and Yadava, D. 2011. Genetic and pathogenic variability of Indian strains of Xanthomonas campestris pv. campestris causing black rot disease in crucifers. Curr. Microbiol. 63:551-560.

Slusarenko, A. J., Fraser, R. S., and van Loon, L. C. 2000. Mechanisms of Resistance to Plant Diseases. Kluwer Academic Publishers, Dordrecht, Boston.

Starr, M. P. 1981. The genus Xanthomonas. The Prokaryotes. M. P. Starr, H. Stolp, H. G. Truper, A. Balows, and H. G. Schlegel, eds. Springer-Verlag, New York.

Staub, T., and Williams, P. H. 1972. Factors influencing black rot lesion development in resistant and susceptible cabbage. Phytopathology 62:722-728.

Sutton, J. C., and Williams, P. H. 1970a. Comparison of extracellular polysaccharide of Xanthomonas campestris from culture and from infected cabbage leaves. Can. J. Bot. 48:645-651.

Sutton, J. C., and Williams, P. H. 1970b. Relation of xylem plugging to black rot lesion development in cabbage. Can. J. Bot. 48:391-401.

Tamura, K., and Nei, M. 1993. Estimation of the number of nucleotide substitutions in the control region of mitochondrial DNA in humans and chimpanzees. Mol. Biol. Evol. 10:512-526.

Tamura, K., Stecher, G., Peterson, D., Filipski, A., and Kumar, S. 2013. MEGA6: Molecular evolutionary genetics analysis version 6.0. Mol. Biol. Evol. 30:2725-2729.

Tancos, M. A., Lange, H. W., and Smart, C. D. 2015. Characterizing the genetic diversity of the New York Clavibacter michiganensis subsp. michiganensis population. Phytopathology 105:169-179.

Thieme, F., Koebnik, R., Bekel, T., Berger, C., Boch, J., and Büttner, D. 2005. Insights into genome plasticity and pathogenicity of the plant pathogenic bacterium Xanthomonas campestris pv. vesicatoria revealed by the complete genome sequence. J. Bacteriol. 187:7254-7266.

Tsygankova, S. V., Ignatov, A. N., Boulygina, E. S., Kuznetsov, B. B., and Korotkov, E. V. 2004. Genetic relationships among strains of Xanthomonas campestris pv. campestris revealed by novel rep-PCR primers. Eur. J. Plant Pathol. 110:845-853.

Valverde, A., Hubert, T., Stolov, A., Dagar, A., Kopelowitz, J., and Burdman, S. 2007. Assessment of genetic diversity of Xanthomonas campestris pv. 
campestris isolates from Israel by various DNA fingerprinting techniques. Plant Pathol. 56:17-25.

Vauterin, L., Hoste, B., Kesters, K., and Swings, J. 1995. Reclassification of Xanthomonas. Int. J. Syst. Bacteriol. 45:472-489.

Versalovic, J., Schneider, M., De Bruijn, F. J., and Lupski, J. R. 1994. Genomic fingerprinting of bacteria using repetitive sequence-based polymerase chain reaction. Methods Mol. Cell. Biol. 5:25-40.

Vicente, J. G., Everett, B., and Roberts, S. J. 2006. Identification of isolates that cause a leaf spot disease of Brassicas as Xanthomonas campestris pv. raphani and pathogenic and genetic comparison with related pathovars. Phytopathology 96:735-745.

Vicente, J. G., Conway, J., Roberts, S. J., and Taylor, J. D. 2001. Identification and origin of Xanthomonas campestris pv. campestris races and related pathovars. Phytopathology 91:492-499.

Vicente, J. G., Ignatov, A. N., Conway, J., Roberts, S. J., and Taylor, J. D. 1998. Development of an improved Brassica differential series for the identification of races of Xanthomonas campestris pv. campestris. Page 271 in: 7th International Congress of Plant Pathology. British Society for Plant Pathology, Edinburgh, Scotland.
Walcott, R. R. 2003. Detection of seedborne pathogens. HorTechnology. 13: 40-47.

White, H. E. 1930. Bacterial spot of radish and turnip. Phytopathology 20: 653-662.

Wicker, E., Lefeuvre, P., de Cambiaire, J.-C., Lemaire, C., Poussier, S., and Prior, P. 2012. Contrasting recombination patterns and demographic histories of the plant pathogen Ralstonia solanacearum inferred from MLSA. ISME J. 6:961-974.

Williams, P. H. 1980. Black rot: A continuing threat to world crucifers. Plant Dis. 64:736-742.

Wilson, E. E., Zeitoun, F. M., and Fredrickson, D. L. 1967. Bacterial phloem canker, a new disease of Persian walnut trees. Phytopathology 57:618-621.

Zaccardelli, M., Campanile, F., Moretti, C., and Buonaurio, R. 2008. Characterization of Italian populations of Xanthomonas campestris pv. campestris using primers based on DNA repetitive sequences. J. Plant Pathol. 90:375-381.

Zhao, Y., Damicone, J. P., Demezas, D. H., and Bender, C. L. 2000. Bacterial leaf spot diseases of leafy crucifers in Oklahoma caused by pathovars of Xanthomonas campestris. Plant Dis. 84:1008-1014. 